\title{
Nosocomial Infections in Very Preterm Neonates - Improvements by Further Scientific Research or Discussions in Talk Shows?
}

\section{Gortner}

Bibliography DOI http://dx.doi.org/ $10.1055 / \mathrm{s}-0033-1334959$ Klin Padiatr 2013; 225: 55-56 (c) Georg Thieme Verlag KG Stuttgart · New York ISSN 0300-8630

Correspondence Prof. Dr. Ludwig Gortner Current Address: Department of Paediatrics and Adolescent Medicine

Medical University of Vienna Währinger Gürtel 18-20 1090 Vienna

Austria

ludwig.gortner@meduniwien. ac.at
Nosocomial sepsis in very preterm neonates (gestational age <32 weeks) has considerable implications in terms of acute mortality or lifethreatening morbidity and the risk of long-term sequelae $[5,11,19,20]$. During the past decade, nosocomial gram-negative translocation sepsis and necrotizing enterocolitis have been researched extensively with the aim to identify molecular, immunologic and clinical risk factors [17]. Molecular factors, such as polymorphisms in genes controlling local immunity and cell-tocell-communication [17], immunologic risk factors including quantitative and qualitative specifics in complement components and innate immunity [10] as well as phagocytic activity and immunoglobulines [5] among others, have been identified as contributing factors in the development of the nosocomial sepsis. New and highly specific and sensitive diagnostic tools have been developed in order to identify neonates with sepsis early on [12]. Furthermore, in large clinical trials additional risk factors have been identified, those include, among others, vascular access for providing parenteral nutrition as well as babies who were born with a low birth weight following impaired intrauterine growth (IUGR - Intrauterine Growth Restriction) [7,15]. Even the colonization with causative agents of nosocomial sepsis has been proven to be associated with the degree of neonatal immaturity and birth weight [14]. One major step in understanding the pathophysiology of nosocomial sepsis and necrotizing enterocolitis was the finding that microbial translocation from the neonatal intestine could explain a major part of the pathogenesis of necrotizing enterocolitis as well as nosocomial gram-negative translocation sepsis [17]. It has been shown that the immaturity of the local immune system within the intestine, cell-to-cellcommunication and cell-mediated immunity are key players in the high susceptibility of very preterm neonates for developing gram negative sepsis $[10,17]$.

On the basis of our improved knowledge, a number of immunologic interventions were investigated in carefully controlled clinical trials, such as the administration of hematologic growth factors (GM-CSF and G-CSF) and intravenous and oral immunoglobulines, among others. So far, none of these concepts proved to be effective in reducing neither necrotizing enterocolitis nor nosocomial sepsis $[5,6,9]$.

However, it had been clear for more than 2 decades that breast milk may reduce the frequency of nosocomial sepsis and necrotizing enterocoli- tis. This also has recently been proven for the administration of lactoferrin [13] and probiotics [8]. The adoption of a standardized nutritional regimen in very preterm neonates has further been shown to reduce above-mentioned complications [16].

Additionally, a decline of nosocomial infections was achieved through the implementation of programs for quality improvement through improved catheter care [11]. Moreover, national programs for quality control in neonatal care with respect to nosocomial infections (NEO-KISS program, Germany) [12] were also able to impact on the reduction of the severity of infections.

It is also known from registers in other settings that outcomes can be improved [18]. Registers, when using similar criteria, enable the scientific community to compare mortality and morbidity rates of e.g. nosocomial sepsis in very low birth weight neonates, who were cared for in different geographical regions: For example, the reported rates of nosocomial infections from a large German national network (German Neonatal Network, GNN) were recently reported to be between 9 and $10 \%$ and compared with the data from the Vermont-Oxford Network mainly enrolling neonates from North America, which was reported to be between 17 and 18\%. Definitions of nosocomial infections and enrollment criteria, i.e., birth weight categories, were identical in both registers.

However, how do those improvements in the better understanding of the pathophysiology of nosocomial infections and the related progress in the field of neonatology translate into the German public perception in print and electronic media? During the past decade, a number of series of nosocomial infections attracted a considerable public interest in Germany. Public awareness has increased considerably during the last 3 years in particularly through the clusters of infections in various neonatal intensive care units in Berlin, Charité [2], Bremen [3] and in Mainz [1].

The leitmotif of all discussions in the public on nosocomial infections appears to be poor hygiene and public opinion seems to indicate that high numbers of infections could be prevented by improving hygienic measures, thereby ignoring the high risk state of very preterm neonates and the above outlined complex pathophysiology [4]. Through the press, it further has been suggested that several thousands of deaths could be readily prevented by improving basic hygienic measures in neonatal intensive care units [4]. 
Thus, there seems to be an increasing gap in the progress we were able to achieve with respect to understanding and preventing nosocomial infections in very preterm neonates and the public perception. This appears to be compounded by willful ignorance and sensational press. The longing for oversimplification along with aforementioned factors threatens the care for severely sick and susceptible neonates in German neonatal intensive care units by affecting the atmosphere of trust. Thus, German neonatology went from being the darling of the press to be the whipping boy. No parallels to this development have been reported from other developed countries.

It is the strong hope of the editor that the substantial progress that had been made by reducing nosocomial translocation sepsis in very preterm neonates will continue, e.g. by a targeted use of lactoferrin, probiotics and immune modulation. This in turn will enable us to further improve neonatal outcome with respect to mortality and long-term morbidity secondary to nosocomial infections. An objective dialogue between the German scientific neonatal community and investigative journalists is mandatory in order to regain a climate of confidence in German neonatal intensive care units, which got lost during the past decade secondary to above-mentioned events. The responsibility of media does not end in the quote of the viewers or the company's profit.

\section{References}

1 Debatte um Krankenhaushygiene. Klinik sieht keinen Zusammenhang mit toten Babys. Stern.de. 24.08.2010 http://www.stern.de/pano rama/debatte-um-krankenhaus-hygiene-klinik-sieht-keinen-zusam menhang-mit-toten-babys-1596330.html

2 Berliner Frühchenstation: Charité weist Kritik an Hygiene-Zuständen zurück. Spiegel online. 23.10.2012( http://www.spiegel.de/wissen schaft/medizin/totes-fruehgeborenes-charite-weist-kritik-an-hy giene-zustaenden-zurueck-a-862979.html

3 Untersuchungsausschuss: Abschlussbericht zum Keim-Skandal. Radio Bremen. 03.12.2012 http://www.radiobremen.de/politik/dossiers/ krankenhauskeime/untersuchungsausschuss/ua-krankenhauske ime172.html

4 Hygienemängel in deutschen Kliniken: Krieg um die Keime. Spiegel online. 04.05.2012 http://forum.spiegel.de/f22/hygienemaengeldeutschen-kliniken-krieg-um-die-keime-60284.html

5 Bersani I, Speer CP. Nosocomial sepsis in neonatal intensive care: inevitable or preventable? Z Geburtshilfe Neonatol 2012; 216: 186-190

6 Carr $R$, Brocklehurst $P$, Dore $C J$ et al. Granulocyte-macrophage colony stimulating factor administered as prophylaxis for reduction of sepsis in extremely preterm, small for gestational age neonates (the PROGRAMS trial): a single-blind, multicentre, randomised controlled trial. Lancet 2009; 373: 226-233
7 Gmyrek D, Koch R, Vogtmann C et al. Risk-adjusted assessment: lateonset infection in neonates. Z Evid Fortbild Qual Gesundhwes 2011; 105: 124-132

8 Guthmann F, Kluthe C, Buhrer C. Probiotics for prevention of necrotising enterocolitis: an updated meta-analysis. Klin Padiatr 2010; 222: 284-290

9 INIS Collaborative Group. Brocklehurst P, Farrell B et al. Treatment of neonatal sepsis with intravenous immune globulin. N Engl J Med 2011; 365: 1201-1211

10 Israels J, Frakking FN, Kremer LC et al. Mannose-binding lectin and infection risk in newborns: a systematic review. Arch Dis Child Fetal Neonatal Ed 2010; 95: F452-F461

11 Kaplan HC, Lannon C, Walsh MC et al. Ohio statewide quality-improvement collaborative to reduce late-onset sepsis in preterm infants. Pediatrics 2011; 127: 427-435

12 Leistner R, Piening B, Gastmeier $P$ et al. Nosocomial infections in very low birthweight infants in Germany: Current data from the national surveillance system NEO-KISS. Klin Padiatr 2013; 225: 75-80

13 Manzoni P, Rinaldi M, Cattani S et al. Bovine lactoferrin supplementation for prevention of late-onset sepsis in very low-birth-weight neonates: a randomized trial. JAMA 2009; 302: 1421-1428

14 Maraqa NF, Aigbivbalu L, Masnita-Iusan C et al. Prevalence of and risk factors for methicillin-resistant Staphylococcus aureus colonization and infection among infants at a level III neonatal intensive care unit. Am J Infect Control 2011; 39: 35-41

15 Samanta S, Farrer K, Breathnach A et al. Risk factors for late onset gram-negative infections: a case-control study. Arch Dis Child Fetal Neonatal Ed 2011; 96: F15-F18

16 Sergeyev E, Gebauer C, Knupfer $M$ et al. Enteral feeding volume advancement by using a standardized nutritional regimen in preterm infants $</=1,750 \mathrm{~g}$ birth weight: a controlled randomized trial. Klin Padiatr 2011; 23: 15-21

17 Sherman MP. New concepts of microbial translocation in the neonatal intestine: mechanisms and prevention. Clin Perinatol 2010; 37: 565-579

18 Stein A, Keller M, Ross S et al. Pandemic A/H1N1(2009) influenza infections in very-low-birth-weight infants - a case series from the German Neonatal Network. Klin Padiatr. 2011; 223: 267-270

19 Stichtenoth G, Demmert M, Bohnhorst B et al. Major contributors to hospital mortality in very-low-birth-weight infants: data of the birth year 2010 cohort of the German Neonatal Network. Klin Padiatr. 2012; 224: 276-281

20 Stoll BJ, Hansen NI, Adams-Chapman I et al. Neurodevelopmental and growth impairment among extremely low-birth-weight infants with neonatal infection. JAMA 2004; 292: 2357-2365 